\title{
Students Satisfaction on Blended Learning in School of Sport Sciences
}

\author{
1Aida Al Awamleh* \\ ${ }^{1}$ Department of Instruction and Supervision, Faculty of Physical Education, University of Jordan, Amman, \\ Jordan.
}

Submitted 30 September 2019; Accepted in final form 10 November 2019.

\begin{abstract}
Background. Blended learning requires a virtual learning and online environment (VLE), which make available a process for establishing learning communities. The Faculty of Physical Education at the University of Jordan designed a number of courses which incorporate blended learning with contact classes and online components on an e-learning models. Objectives. Of the present study is to investigate if modes of BL possible influence on students' perceived achievement goals and satisfaction. Methods. The research model is tested using a questionnaire survey. Eighty-three undergraduate sport students participated in the courses (Motor Learning) offered by the University's Faculty of Physical Education the participants were divided in two groups. Results. Indicated that students were satisfied with blended program and online learning environment; satisfaction was generally high with $83.4 \%$. The results also show that BL rotation type (students rotate between online and traditional content on fixed schedule) significantly affects learning satisfaction. Moreover, the quality of the teaching received the highest satisfaction level where interaction significantly affected self-study. Conclusion. The feedback of students who are amongst the key stake holders is essential to ensure a successful implementation of bended learning.
\end{abstract}

\section{KEYWORDS: Blended Learning, Students' Satisfaction, Motor Learning}

\section{INTRODUCTION}

The world is rapidly changing. Universities all around the globe are now implementing and investing in Virtual Learning Environment which paves the way to deliver 'Blended learning', learning management systems are used in higher education context. The reviewed literature revealed several definition of blended learning. From training perspective, blended learning can be described as an effective learning model with suitable supporting technology coupled with appropriate mix of teaching techniques. This combines a mix of ICT (Information and Communication Technology) with various delivery methods and learning resources. Blending learning typically consist of $30 \%$ to
$79 \%$ online content delivery (1). Blended learning is one of the most innovative methodologies in the field of education. It has changed the techniques of information delivery and classroom management. (2).

Naaj et al. (2012) and Garrison \& Kanuka (2004) found that BL program encourages a type of communication between lecturer and student that balances between stable cohesive influence and limitless access to information on the Internet $(3,4)$. Blended learning allows for further options for students to study in the place and at the pace of their choice in form of digital communication technologies. Wu et al. (2010) indicate that BL raises collaboration between students where they

*. Corresponding Author:

Aida Al Awamleh, Professor

E-mail: Aida.awamleh@ju.edu.jo 
define concept of blended learning as "a learning approach that combines between different delivery methods and styles of learning (5). The blend could be between any form of instructional technology with classroom teaching such as videotape, CD-ROM, Computer Assisted Instruction CAI) and web-based learning (6). The study conducted by le Roux and Nagel (2018) indicates that the use of online videos helped students better understand the theoretical underpinnings of the course $(7,8)$.

"...its ability to facilitate a community of inquiry. Community provides the stabilizing, cohesive influence that balances the open communication and limitless access to information on the Internet. Communities also provide the condition for free and open dialogue, critical debate, negotiation and agreement-the hallmark of higher education. Blended learning has the capabilities to facilitate these conditions and adds an important reflective element with multiple forms of communication to meet specific learning requirements" (4).

The types of blended learning are: face-to-face (driver content mostly delivered traditionally), rotation (student rotate between online and traditional content on fixed schedule), flex (content delivered online with traditional sessions providing - if needed - online lab sessions at a traditional location), self-blend (student chooses to take online course to supplement traditional learning), and online driver (lectures delivered mostly online with some voluntary traditional application) (9). Higher education institutions adopt blended learning as a formal education program, in which a student learns partly through online delivery of content (10).

Instructions with some element of student's ability to have control over time, place, path, and/or pace etc can be available, aided by textbooks, manuals, recitations, demonstrations, quizzes, and examinations. The courses are offered can be considered as blended if they incorporate $30 \%$ to $79 \%$ of online content delivery (9).

Blended learning in Faculty of Sport Sciences provides the perfect combination of online and traditional content on fixed schedule, which is ideal for those balancing their study work alongside other professional or sporting commitments. Student put theory into practice through applied studies and measurement as well as sport-specific models. Furthermore, blended learning program provides opportunities to develop student management skills in motor learning and understanding knowledge (11).

Johnson et al. (2014) reports that "the Internet is capturing more and more of our time each day - with total hours spent online via PCs, laptops, mobiles and tablets growing from 5.55\% in 2012 to $6.15 \%$ in 2014 " (12). In a major meta-analysis of research on blended and online learning for the U.S. Department of Education Means et al. (2009; 2010) reported that blended instruction has been more effective, providing a rationale for the effort required designing and implementing blended approaches. When used by itself, online learning appears to be as effective as conventional classroom instruction $(13,14)$.

Rienties et al. (2015) indicates that satisfaction with blended learning represents a key concern for higher education stakeholders, they are becoming an increasingly competitive market. Student satisfaction has become an important component of Quality Assurance and Quality Enhancement (15). Many student in Canadian universities preferred blended learning (16). Castle \& McGuire (2010) found that students show greater satisfaction in blended courses than in traditional lectures (17). Woods (2002) and Chen, \& Chen (2007) findings that were a significant positive relationship between students' perceived course interaction and their satisfaction in blended courses $(18,19)$.

Faculty of Physical Education at the University of Jordan modified a physical education modules to suit VLE settings. Currently the Faculty offers more than 35 blended learning courses for undergraduate and graduate students. Learner satisfaction can be easily attained by implementing distinguishable factors involving interacting with the blended learning by students, and to evaluate student's satisfaction is of great importance to higher education institutions as it helps them to pinpoint the strengths and to identify areas for improvement, especially in sport science institutions.

Objectives. The objectives of the study were to:

Present reactions of students undergoing an ICT-based blended learning environment in the Motor learning course.

Measure the extent of students' satisfaction with the blended course that they participated in for sixteen weeks. 
Investigate the level of satisfaction based on benefiting from the course, lecture quality, ability to use the VLE (E-learning), enhancing learning, confidence in using E-learning and the ability to interact with other students during days of lectures, Monday through Tuesday.

Hypotheses. There are differences in the overall level of satisfaction with blended learning based on enhancing learning ability to use VLE (E-learning), lecture quality, confidence, interaction, benefit. Another factor was the day a lecture is given.

\section{MATERIALS AND METHODS}

Population and Sampling. This study was conducted in the University of Jordan, School of Physical Education. A total of (83) undergraduate sport students (41 males, 42 females) were divided into two groups (A) 40 and (B) 43, including those who attended the ninety-minute lectures on Mondays and Wednesdays, and those who attended the sixty-minute lectures on Sundays, Tuesdays and Thursdays (ninety-minute and sixty-minute for a lecture which is equal to 180 minutes for both three-session or two-session lecture per week). The same lecturer taught both classes. For this project, the station rotation model was used, the students rotate on a fixed schedule or at the lecturer's discretion between learning modes; one of which is online learning. For example, Thursdays were online meeting while Sundays and Tuesdays were the face-to-face technique. Blended learning included activities such as small-group, full-class instruction, group projects, individual tutoring, quizzes, assignments and short writing assignments. The online section was inclusive of analysis videos, which are available online, or creating some videos related topics. Students were given time to work on online reading assignments, forum outside the classroom. Students submitted all tasks electronically, and they were able to keep track of their progress and marks. All students were dealt with individually, and all the data were systematically coded and processed using SPSS. The study was granted approval from the University of Jordan, Faculty of Physical Education; all participants submitted their written consent to take part in the study. Participants completed the questionnaire independently under the researcher's supervision.

Study Instruments and Validation Procedure. The instrument was adapted from various sources which have been proven to be reliable and valid. The alpha reliability coefficient of the scale was found as 0.93 indicating that the instrument was reliable (Table 1). A questionnaire was designed by the University of Jordan blended learning group and validated by four experts at the Faculty of Physical Education. Statements in the questionnaire were categorized into six main domains; lecture quality, benefit, learning, confidence, interaction, and ability to use VLE.

The scoring for the questionnaire was established following the five-point Likert Scale: strongly agree, agree, neutral, disagree, and strongly disagree, with scores of five points.

Table 1. Internal Consistency Cronbach's Alpha Reliability for the Satisfaction on Blended Learning Domains

\begin{tabular}{|lccc|}
\hline Items & Domains & $\begin{array}{c}\text { Number of } \\
\text { Statements }\end{array}$ & $\begin{array}{c}\text { Cornbach's } \\
\text { alpha value }\end{array}$ \\
$\mathbf{2 2 , 1 1 , 4 , 2 , 1}$ & Learning & 5 & 0.91 \\
$\mathbf{6 , 8 , 7 , 9}$ & Self-confident & 4 & 0.85 \\
$\mathbf{1 0 , 3}$ & $\begin{array}{c}\text { Interaction } \\
\text { Ability to use } \\
\text { the VLE }\end{array}$ & 2 & 0.60 \\
$\mathbf{1 5 , 1 2 , 1 3 , 1 4}$ & $\begin{array}{c}\text { (E-learning) } \\
\text { (20,18,19,17, }\end{array}$ & $\begin{array}{c}\text { Lecture } \\
\text { quality }\end{array}$ & 0.71 \\
$\mathbf{1 6}$ & benefit & 2 & 0.92 \\
$\mathbf{5 , 2 1}$ & Total & 22 & 0.80 \\
& & & 0.93 \\
\hline
\end{tabular}

\section{RESULTS}

In order to address the research hypotheses of the present study, Table 2 provides basic statistics regarding the mean and Std. Deviation for each domain. The extent of students' satisfaction with the blended course that they participated in for sixteen weeks was high, M was (4.17). The majority of students were satisfied with BL with $83.4 \%$.

Table 2. Means and Standard Deviations of Satisfaction level on Blended Learning Courses

\begin{tabular}{|c|c|c|c|c|c|}
\hline $\begin{array}{l}\text { Items } \\
\text { number }\end{array}$ & Domains & Mean & SD & $\begin{array}{c}\text { Percent } \\
\%\end{array}$ & Place \\
\hline $\begin{array}{l}20,18,1 \\
9,17,16\end{array}$ & Lecturer quality & 4.61 & $\begin{array}{c}0.6 \\
1\end{array}$ & 92.20 & 1 \\
\hline 5,21 & $\begin{array}{c}\text { The degree of } \\
\text { benefiting from } \\
\text { the course }\end{array}$ & 4.43 & $\begin{array}{c}0.7 \\
1\end{array}$ & 88.60 & 2 \\
\hline $\begin{array}{l}22,11,4 \\
, 2,1\end{array}$ & $\begin{array}{c}\text { Enhancing } \\
\text { learning }\end{array}$ & 4.18 & $\begin{array}{c}0.8 \\
7\end{array}$ & 83.60 & 3 \\
\hline $6,8,7,9$ & Self-confident & 4.08 & $\begin{array}{c}0.8 \\
7\end{array}$ & 81.60 & 4 \\
\hline 10,3 & Interaction & 3.89 & $\begin{array}{c}0.9 \\
7\end{array}$ & 77.80 & 5 \\
\hline \multirow[t]{2}{*}{$\begin{array}{l}15,12,1 \\
3,14\end{array}$} & $\begin{array}{l}\text { Ability to use } \\
\text { the VLE } \\
\text { (E-learning) }\end{array}$ & 3.82 & $\begin{array}{c}0.8 \\
2\end{array}$ & 76.40 & 6 \\
\hline & Total & 4.17 & $\begin{array}{c}0.6 \\
4\end{array}$ & 83.40 & \\
\hline
\end{tabular}




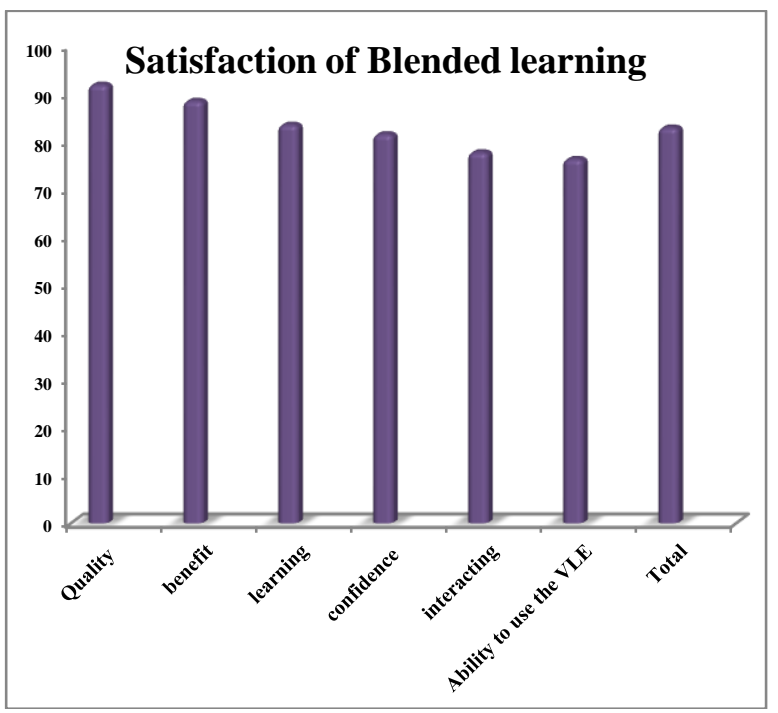

Figure 1. Blended Learning Satisfaction on Motor Learning Courses

To identify the differences on satisfaction level of blended learning courses regarding to the course day, the T-Test was used to determine if there is significant difference between two groups which may be related to the course day. The results indicated that there were no significant difference between two groups, only on Lecture quality domain. The students were more satisfied with Monday and Wednesday lectures than Sunday, Tuesday and Thursday lectures.

Table 3. Differences on Satisfaction Level of Blended Learning Courses Regarding the Course Day

\begin{tabular}{|c|c|c|c|c|c|}
\hline Participations Days & $\mathbf{N}$ & $\mathbf{M}$ & SD & $\mathbf{T}$ & SIG \\
\hline \multicolumn{6}{|c|}{$22,11,4,2,1$} \\
\hline Learning & & & & 0.76 & 0.448 \\
\hline $\mathrm{M}, \mathrm{W}$ & 40 & 4.10 & 0.90 & & \\
\hline S,TU,TH & 43 & 4.25 & 0.85 & & \\
\hline \multicolumn{6}{|c|}{$6,8,7,9$} \\
\hline Self-confident & & & & 1.88 & 0.063 \\
\hline $\mathrm{M}, \mathrm{W}$ & 40 & 3.89 & 0.94 & & \\
\hline S,TU,TH & 43 & 4.25 & 0.78 & & \\
\hline \multicolumn{6}{|c|}{10,3} \\
\hline Interaction & & & & 0.20 & 0.836 \\
\hline $\mathrm{M}, \mathrm{W}$ & 40 & 3.86 & 1.03 & & \\
\hline S,TU,TH & 43 & 3.91 & 0.93 & & \\
\hline \multicolumn{6}{|c|}{$15,12,13,14$} \\
\hline $\begin{array}{l}\text { Ability to use the VLE } \\
\text { (E-learning) }\end{array}$ & & & & 0.39 & 0.694 \\
\hline $\mathrm{M}, \mathrm{W}$ & 40 & 3.86 & 0.71 & & \\
\hline S,TU,TH & 43 & 3.78 & 0.91 & & \\
\hline \multicolumn{6}{|c|}{$20,18,19,17,16$} \\
\hline Lecture quality & & & & 2.55 & 0.013 \\
\hline $\mathrm{M}, \mathrm{W}$ & 40 & 4.79 & 0.39 & & \\
\hline S,TU,TH & 43 & 4.46 & 0.73 & & \\
\hline \multicolumn{6}{|c|}{5,21} \\
\hline benefit & & & & 1.77 & 0.081 \\
\hline $\mathrm{M}, \mathrm{W}$ & 40 & 4.58 & 0.57 & & \\
\hline S,TU,TH & 43 & 4.30 & 0.80 & & \\
\hline Total & & & & 0.14 & 0.882 \\
\hline $\mathrm{M}, \mathrm{W}$ & 40 & 4.18 & 0.59 & & \\
\hline S,TU,TH & 43 & 4.16 & 0.68 & & \\
\hline
\end{tabular}

\section{DISCUSSION}

Blended courses and E-learning seem to be the upcoming trend. Within the last decades, many lecturers and teachers have developed teaching methods aiming at raising the efficiency of education. The outcome of such development resulted in one educational method referred to as "blended learning", which proved effective in enhancing the ability of the lecturers and teachers to deliver information through practical application.

The current study found that the extent of students' satisfaction with the blended course was high and the quality of lecture was most important in influencing student satisfaction, such as lecturer has competence in motor learning; iinstructional strategies that lecturer used stimulated the students to explore, discover, and think critically. Some statements asked students if the lecturer has good motivation skills, or lecturer guides students along a continuum of learning from awareness of new techniques to adapt and apply such techniques in their own professional settings. For example, one of Lecture quality statement : says 'my professor can use online learning environment confidently'. The researcher found that students who were motivated and invested their effort in the blended learning course were more likely to express higher satisfaction with the course (20). Other important factors influencing student satisfaction was the degree of benefiting from the course, it received $88.6 \%$; 'I feel that I learnt a lot through blended learning course'. Figure 1 shows blended learning satisfaction domains. The results also showed that $76.4 \%$ of students were satisfied with the ability to use Virtual Learning Environment. The application of blended learning allows students to work according to their needs and circumstances with no restrictions of time, place and method. This approach can be used by individuals or groups during practice, training and project implementation with the choice of Internet use. This approach has many advantages, such as ease of access to resources and equal opportunities in education and saving on expenses.

Although students encountered some technical problems, they preferred to deal with the possible challenges instructors and learners using various electronic tools, watching videos to enhance learning opportunities of them. BL program encourages the type of communication and 
interaction between lecturer and student. There are a variety of ways for students to collaborate online, via MOOC, Moodle, EDMODO (21). The researcher used Moodle which is a Learning Platform, it is a free Open Source software package designed to help educators create effective online courses.

The current study showed interaction factor was $77.8 \%$ of students. Some researchers indicted that blended learning increases collaboration between students and Lecturer $(3-5,22)$. In current study, enhancing learning through (Elearning) using blended instruction has been more effective $83.6 \%$ of students rated it. The degree of benefiting from the course of using blended instruction was $88.6 \%$.

The U.S. Department of Education found that blended instruction combining online and face-toface elements had a larger advantage than purely online instruction (13). Because of the flexible structure of online learning instruction, students can control when and where they learn. They are able to spend more time on unfamiliar or difficult content by self-monitoring their time and pace of learning (23). Bralic and Divjak's (2018) found that the students opting to follow the MOOC instead of doing project work is increasing each academic year (24). Because students can learn at their own pace, receive peer support, and gain regular assessment feedback via BL (25).

Data analysis revealed that students were quite satisfied with the overall learning experience regarding to the course day, particularly as they relate they were more satisfied with Monday and Wednesday lectures than Sunday, Tuesday and Thursday lectures. This means that blended learning needs an active lecturer in order to ensure the success of the content being delivered and the technology used to enhance the learning opportunities of the students. This means that transformation to blended learning must be done after the selection of lecturers which is a process that is based on assessing lecturer's understanding and ability to use several techniques. Further, this requires a change in the role of the lecturer in planning, delivering lectures as well as evaluation system.

Lectures on these days take one hour per day, and every Thursday there was online meeting, whereas Monday and Wednesday lectures take one hour and half per day for the first month (no online class after one month), the meeting schedule is face-to-face on Monday lectures, and
Wednesday lectures were online. For sport students, blended learning course provides the perfect combination of online and traditional content on fixed schedule, which is ideal for those balancing their studies alongside other professional or sporting commitments. Student put theory into practice through applied studies and measurement, sports-specific modules. Furthermore, blended learning program provides opportunities to develop student management skills in motor learning and understanding knowledge and self-study.

\section{CONCLUSION}

The main aim of the study was to determine the BL satisfaction level in motor learning course. Blended learning environment at the University of Jordan is designed to provide the student with an opportunity to gain or enhance self-study, it is just one example of how technology, including Internet, coupled with increasingly powerful and portable computers can be leveraged to enrich the learning process. In 2017 the University of Jordan modified a physical education module to where it can be presented with a virtual learning environment.

The researcher implemented blended learning on motor learning courses for undergraduates for sixteen weeks in School of Sport Sciences. Most students generally preferred the use of the videos which are available online, and to create some videos related to motor learning issues. BL environments allow students to learn at their own pace and place.

The results of the current study show that the $\mathrm{BL}$ is the future and the best way to make the most of lecture time, simply bringing technology into the classroom is not enough in itself, the teachers and the students must be trained to use technology. The communications of the senior management of the university with colleges, the investigation of nature of theoretical and practical materials as well as the preparation of both teacher and student to implement technology are the basic elements for the success of such approach.

Enhancing teacher's experience, on how to work with technology, and how to make use of the lectures are among the most important elements of successful learning. The effort in planning the lesson lies on the lecturer. This means that blended learning needs an active lecturer in order to ensure the success of the content being delivered and the technology used 
to enhance the learning opportunities of the students.

\section{APPLICABLE REMARKS}

- The results found that students were satisfied with blended program and online learning environments; satisfaction was generally high.

-Future research might also be conducted to determine students' satisfaction levels including theoretical and practical courses.

-It would be beneficial to replicate this study with a larger population sample in other faculties. Although this study endeavored to assess students' blended learning satisfaction level in school of Sports Sciences, the results of this study and the research that supports it provide a strong rationale for why including blended learning in sport school or in higher education programs is important.

-Focusing on high quality lectures, improving the ability to use VLE (e-learning) and creating opportunities for students to develop their selfstudy could also help sport institutions to maintain high levels of student satisfaction on blended learning.

\section{REFERENCES}

1. Kyei-Blankson L, Ntuli E. Practical Applications in Blended Learning Environments: Experiences in K-20 Education. USA2014.

2. Galvis ÁH. Supporting decision-making processes on blended learning in higher education: literature and good practices review. Int J Educ Technol High Educ. 2018;15(1):25. doi: 10.1186/s41239018-0106-1

3. Abou Naaj M, Nachouki M, Ankit A. Evaluating Student Satisfaction with Blended Learning in a Gender-Segregated Environment. J Inf Technol Educ Res. 2012;11:185 - 200. doi: 10.28945/1692

4. Garrison DR, Kanuka H. Blended learning: Uncovering its transformative potential in higher education. Internet High Educ. 2004;7(2):95-105. doi: 10.1016/j.iheduc.2004.02.001

5. Wu J-H, Tennyson RD, Hsia T-L. A study of student satisfaction in a blended e-learning system environment. Comput Educ. 2010;55(1):155-164. doi: 10.1016/j.compedu.2009.12.012

6. O'Flaherty J, Phillips C. The use of flipped classrooms in higher education: A scoping review. Internet High Educ. 2015;25:85-95. doi: 10.1016/j.iheduc.2015.02.002

7. le Roux I, Nagel L. Seeking the best blend for deep learning in a flipped classroom - viewing student perceptions through the Community of Inquiry lens. Int J Educ Technol High Educ. 2018;15(1). doi: 10.1186/s41239-018-0098-x

8. Mayer RE. Multimedia learning. Cambridge: Cambridge University Press; 2012.

9. Horn MB, Staker H. The rise of K-12 blended learning. New York: Innosight institute; 2011.

10. Porter WW, Graham CR, Bodily RG, Sandberg DS. A qualitative analysis of institutional drivers and barriers to blended learning adoption in higher education. Internet High Educ. 2016;28:17-27. doi: 10.1016/j.iheduc.2015.08.003

11. Alawamleh A. Blended learning in physical education school Jordan: UJ Newsletter; 2018 [cited 2018]. http://newsletter.ju.edu.jo/Lists/InTheSpotLight/Disp_Form.aspx?ID=10\&Issue=2018-08.

12. Johnson L, Becker SA, Cummins M, Estrada V, Freeman A, Hall C. NMC horizon report: 2016 higher education edition: The New Media Consortium; 2016.

13. US Department of Education OoP, Evaluation,, Policy Development. Evaluation of evidence-based practices in online learning: A meta-analysis and review of online learning studies. Washington: Office of Planning, Evaluation and Policy Development; 2009.

14. Means B, Toyama Y, Murphy R, Bakia M, Jones K. Evaluation of evidence-based practices in online learning: A meta-analysis and review of online learning studies. Washington, DC: US: Department of Education; 2009.

15. Rienties B, Li N, Marsh V. Modeling and managing student satisfaction: use of student feedback to enhance learning experience. Gloucester: Quality Assurance Agency; 2015.

16. Owston R, Garrison D, Cook K. Blended e-learning at Canadian universities: issues \& practices. In: Bonk C, Graham C, editors. Handbook of Blended Learning: global Perspectives, \& Local Designs, Pfeiffer Publishing. San Francisco, CA2006. p. 338-350. 
17. Castle SR, McGuire C. An Analysis of Student Self-Assessment of Online, Blended, and Face-toFace Learning Environments: Implications for Sustainable Education Delivery. Int Educ Stud. 2010;3(3). doi: 10.5539/ies.v3n3p36

18. Woods Jr RH. How much communication is enough in online courses?--exploring the relationship between frequency of instructor-initiated personal email and learners' perceptions of and participation in online learning. Int J Instruct Media. 2002;29(4):377.

19. Chen Y-J, Chen P-C. Effects of online interaction on adult students' satisfaction and learning. $J$ Hum Resour Adult Learn. 2007;3(2):78-89.

20. Svanum S, Aigner C. The influences of course effort, mastery and performance goals, grade expectancies, and earned course grades on student ratings of course satisfaction. Br J Educ Psychol. 2011;81(Pt 4):667-679. doi: 10.1111/j.2044-8279.2010.02011.x pmid: 22050312

21. Kaplan AM, Haenlein M. Higher education and the digital revolution: About MOOCs, SPOCs, social media, and the Cookie Monster. Busin Horiz. 2016;59(4):441-450. doi: 10.1016/j.bushor.2016.03.008

22. Vaughan N. Student Engagement and Blended Learning: Making the Assessment Connection. Educ Sci. 2014;4(4):247-264. doi: 10.3390/educsci4040247

23. Aslanian CB, Clinefelter DL. Online college students 2012: Comprehensive data on demands and preferences: Learning House, Incorporated; 2012.

24. Bralić A, Divjak B. Integrating MOOCs in traditionally taught courses: achieving learning outcomes with blended learning. Int J Educ Technol High Educ. 2018;15(1):2. doi: 10.1186/s41239-0170085-7

25. Thurmond V, Wambach $\mathrm{K}$. Towards an understanding of interactions in distance education. Online J Nurs Informatics. 2004;8(2):18. 